\title{
What Types of Cells Could be Isolated from Pericoronal Dental Follicle? Short Communication
}

\section{Zornitsa Mihaylova ${ }^{\star, \dagger}$}

Department of Dental, oral and maxillofacial surgery, Faculty of Dental medicine, Medical University - Sofia

(O) DOI: https://doi.org/10.15520/jcmro.v2i08.192

Accepted 16-08-2019; Received 12-08-2019; Publish Online 16-08-2019

\author{
Reviewed By: Dr Seeja \\ Department: \\ Reviewer/CMRO
}

\begin{abstract}
Human dental follicle (DF) is an ectomesenchymal structure surrounding the tooth germ. It consists of various cells types, as some cells might be associated with cystic degeneration in the neighboring hard tissue. We managed to isolate cells from DF showing different morphological properties.
\end{abstract}

Key words: Dental Follicle-Odontogenic Cysts-Dental Follicle Stem Cells

\section{INTRODUCTION:}

Human dental follicle (DF) is an ectomesenchymal structure surrounding the tooth germ. It is developed due to ectomesenchymal cells condensation around the enamel organ and the dental papilla. The enamel organ forms the tooth enamel, while the dental papilla is associated with the formation of dentine and the pulp; DF is associated with the development of the tooth supporting structures [1]. $\mathrm{DF}$ is a source of mesenchymal stem cells (MSC) capable of giving rise to periodontal ligament cells, cementoblasts, osteoblasts, adipocytes, etc. [2]. After the tooth development has been completed, the DF together with the reduced enamel epithelium are commonly found between the crown of the unerupted tooth and the bone crypt forming the pericoronal follicular tissues [3]. These tissues are considered biological waste after tooth extraction and are seldom given for histopathological evaluation. Pericoronal follicular tissue is found around impacted teeth, most commonly around third molars (wisdoms) and maxillary canines. At the site of the wisdom teeth they may give a rise to odontogenic cysts and tumors.

Histological evaluation of pericoronal DF reveals presence of fibrous connective tissue, nodes of odontogenic epithelium and reduced enamel epithelium [1]. Local stimuli may contribute to the enlargement of the epithelial layer. In normal pericoronal follicular tissues, the epithelium is usually fragmented, probably due to the tight junction of the epithelial layer when compared to the underlying connective tissue. To distinguish the normal widening of the pericoronal space during tooth eruption from dentigerous cysts is a

\footnotetext{
* Corresponding author.

$\dagger$ Email: dr.z.mihaylova@gmail.com
}

common challenge for dental specialists, especially in cases of relatively limited pericoronal radiolucency [4]. Usually, the "diagnosis" is based on radiological findings. According to wide number of studies, a pericoronal radiolucency less than $2,5 \mathrm{~mm}$ is considered DF, while radiolucency larger than this size is taken as a follicular/dentigerous cyst [5].

Currently it is not clear what type of cells could be found in human DF and their properties have to be clarified, as any alteration in these cells might give rise to tooth bearing tissue pathology. To the best of our knowledge there is lack of sufficient reports in the literature about in vitro experiments showing the presence of epithelial cells in human pericoronal follicular tissues, as well as their long-term cultivation. We aimed to isolate cell cultures from human DF and to identify the presence of two morphologically different cell types.

\section{MATERIALS AND METHODS: CELL ISO- LATION AND CULTIVATION}

Cells were obtained from DFs of intact surgically extracted third molars $(n=4)$ of healthy patients $(n=4)$ between 16 and 18 years old, after signing informed and written consent. DFs were separated from the calcified dental structures and washed 3 times with Phosphate-buffered saline (PBS) (Lonza, Verviers, Belgium). Tissue explants were enzymatically digested in a solution of $3 \mathrm{mg} / \mathrm{ml}$ collagenase type $\mathrm{I}$ and $4 \mathrm{mg} / \mathrm{ml}$ dispase (Sigma-Aldrich, St. Louis, MO, USA) for $15-30 \mathrm{~min}$ at $37^{\circ} \mathrm{C}$ and then transferred to $2 \mathrm{~cm}^{2}$ culture dishes with Dulbecco's modified Eagle's medium (DMEM) (Invitrogen, Eugene, OR, USA) supplemented with $1 \%$ antibiotic-antimycotic (Invitrogen) and $10 \%$ heat inactivated fetal bovine serum (FBS) (Sigma-Aldrich). Cell 
cultures were incubated at $37^{\circ} \mathrm{C}$ in humidified atmosphere of $5 \% \mathrm{CO} 2$ and $95 \%$ air for a period of 2 to 4 weeks. The medium was replaced every $2^{\text {nd }}$ or $3^{\text {rd }}$ day thereafter until migrating cells colonies were established. Cell growth was monitored by phase contrast microscopy (Leica DMRE, Leica Microsystems GmbH, Germany).

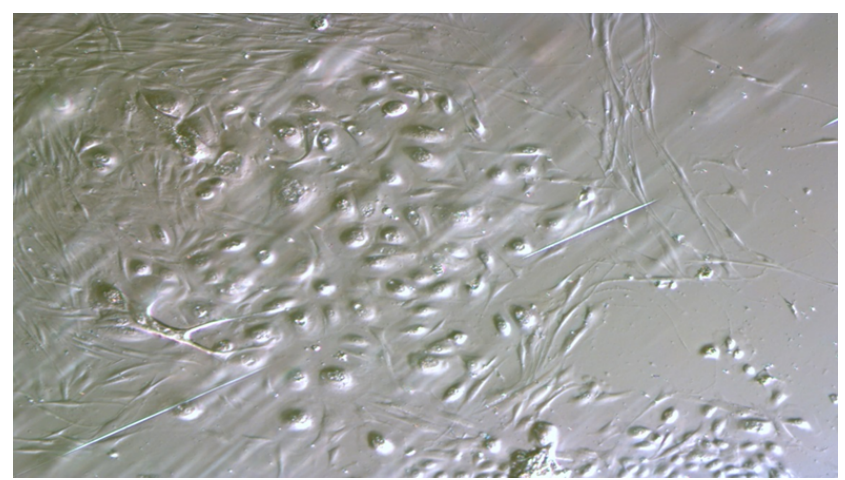

Figure 1. Cells, isolated from human dental follicle

\section{CONCLUSION:}

We identified two different cell types in human pericoronal dental follicular tissues based on their morphology. Long-term cultivation has led to additional morphological changes, as we observed cell enlargement and slow-going replacement of round-shaped cells with typical fibroblast-like cells. Additional research is needed in order to reveal the cell phenotype and to find the most appropriate cell culture conditions for long-term cultivation.

\section{REFERENCES}

[1] Avery JK. Oral Development and Histology. New York: Thieme Medical Publishers; 2002. 3th ed.

[2] Honda MJ, Imaizumi M, Tsuchiya S, Morsczeck C. Dental follicle stem cells and tissue engineering. J Oral Sci. 2010;52(4):541-52.

[3] Mohan BC, Angadi PV. Quantitative and qualitative analysis of epidermal growth factor receptor expression in pericoronal follicles in predicting proliferative potential. Acta Odontol Scand. 2014;72(8):770-775.

[4] Lin HP, Wang YP, Chen HM, Cheng SJ, Sun A, Chiang CP. A clinicopathological study of 338 dentigerous cysts. J Oral Pathol Med. 2013;42(6):462-469.

[5] Dental follicle: role in development of odontogenic cysts and tumours. Dental Folikül: Odontojenik Kist ve Tümörlerin Oluşumundaki Rolü. Journal of Istanbul University Faculty of Dentistry. 2014;48(1):89-96. 